\title{
Illusions prepared as stereograms
}

The loci of organization and the modes of operation of certain perceptual mechanisms may be determined by presenting appropriate stimuli independently to each eye in such a way that they become superimposed in stereoscopic vision. It is possible that understanding of the mechanisms responsible for the appearance of certain "geometrical illusions" may be furthered by adopting this procedure. The two functional components of a sample of illusions are distinguished and illustrated in the form of stereograms.

Theoretical discussions of perceptual phenomena are customarily prefaced by consideration of the possible loci of organization of the mechanisms responsible for their appearances. Subsequently, discussions of this kind are usually followed by descriptions of experimental studies designed in such a way as to allow the broad distinction to be made between "central" and "peripheral" modes of organization and function; whereupon, it frequently proves possible for the mechanism under investigation to be located and identified uniquely. A well-known and widely-used procedure for distinguishing between central and peripheral

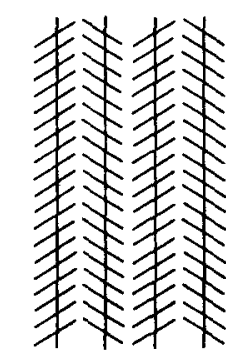

Fig. 1. (a) The Zollner illusion and (b) its distorting and distorted components.

processes is that of presenting stimuli independently to each eye so that they fuse in binocular vision. Thus, one part of the visual information is received at the retina of the left eye and

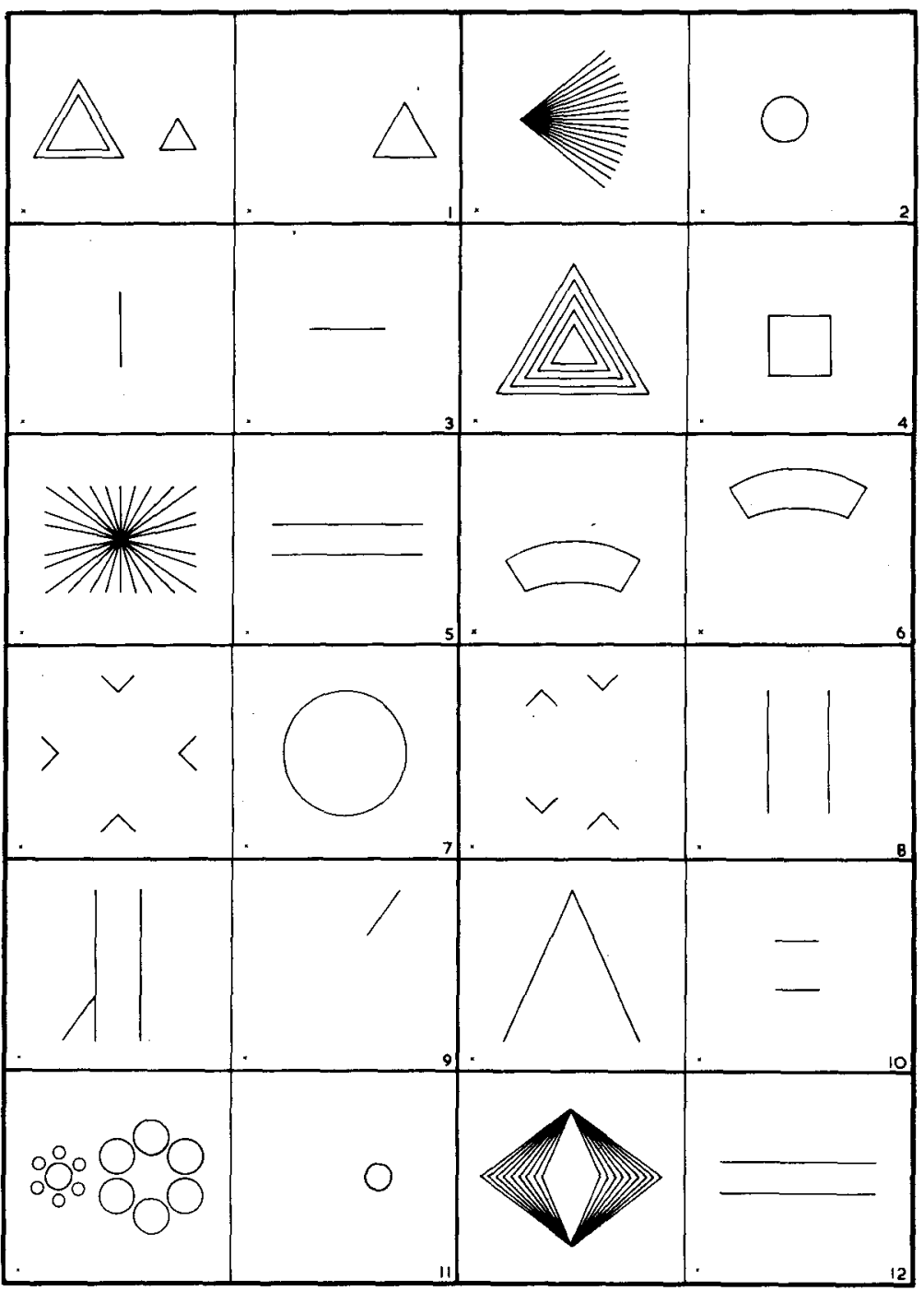

Fig. 2. Illusion-figures prepared in the form of stereograms. 
transmitted along the optic nerve to the chiasma while the other part reaches the chiasma over a similar route via the retinal receptors of the right eye. Should the particular perceptual phenomenon under observation persist in these conditions, it is usually considered reasonable to conclude that the mechanism responsible for its appearance is dependent upon processes operating at some level beyond that of the retinal mosaic.

The physical characteristics and the phenomenal attributes of a number of two-dimensional patterns are markedly different. Certain figures of this kind were first described by Oppel (1855) as "geometrical optical illusions." For more than a hundred years attempts have been made by scientists representing a wide range of professional disciplines to understand the distortions evidenced in illusions; nevertheless, an entirely acceptable explanation of their appearances remains to be developed.

Many examples of spatial patterns which are subject to illusory distortion may be understood as having two functional components, one exerting a distorting influence while the other undergoes it. In the Zöllner (1860) illusion, for example, the vertical lines do not appear parallel due to the presence of the oblique lines superimposed upon them. The typical appearance of this illusion is illustrated clearly in Fig. 1(a). The oblique lines undoubtedly serve to induce this illusory distortion since, when the vertical components are placed beyond the influence of the obliques, their parallel appearance is restored. The distorting and distorted elements of this illusion are shown side by side in Fig. 1(b).

With the use of a stereoscope it is a relatively simple matter to arrange for the two components of illusory spatial patterns to be seen in different eyes. In the author's laboratory this is being achieved using a specially modified version of the Casella, Model S. V. 3. stereoscope. The specific purpose of this paper is to illustrate a standard set of stimulus materials which has been prepared for use in these studies. It should be noted that the form of these materials is such as to be somewhat more suitable for presentation stereoscopically than the patterns described previously by Lau (1922), Day (1961), and Springbett (1961).

The two component elements of each illusion are reproduced in Fig. 2 in such a way that they can be presented immediately as stereograms using even the most rudimentary apparatus. When these patterns are brought into exact registration stereoscopically, by superimposing the small index marks included in the lower left-hand corners, they form the following illusions:

$\begin{aligned} 1 & \text { Delboeuf (1893) } & 2 & \text { Ehrenstein (1924) } \\ 3 & \text { Fick (1851) } & 4 & \text { Gatti (1926) } \\ 5 & \text { Hering (1861) } & 6 & \text { Jastrow (1889) } \\ 7 & \text { Lipps (1891) } & 8 & \text { Müller-Lyer (1889) } \\ 9 & \text { Poggendorff (1860) } & 10 & \text { Ponzo (1912) } \\ 11 & \text { Titchener (1901) } & 12 & \text { Wundt (1898) }\end{aligned}$

The author will be glad to receive any observations which might arise from the use of these materials. In a further paper it is intended to describe a series of studies adopting and developing the technique outlined here for consideration of a variety of spatial patterns which undergo illusory spatial distortion.

\section{REFERENCES}

BURMESTER, E. Beiträge zur experimentellen Bestimmung geometrischoptischer Täuschungen. Z. PsychoL, 1896, 12, 355-394.

DAY, R. H. On the stereoscopic observation of geometrical illusions. Percept. mot Skills, 1961, 13, 247-258.

DELBOEUF, J. L. R. Sur une nouvelle illusion d'optique. Bull, de L'Acad. roy. de Belg., 1893, 24, 545-558.

EHRENSTEIN, w. Versuche über die Beziehungen zwischen Bewegungs- und Gestaltwahmehmung. Z. Psychol, 1924, 95, 305-352.

FICK, A. De errore quodam optico asymmetria bulbi effecto. Marburg: Koch, 1851.

GATTI, A. La percezione dei rapporti spaziali nei complessi visivi. Contributi del laboratorio di Psicol dell U. C. del S. C., 1926, seria II.

HERING, E. Beiträge zur Physiologie, I. Leipzig: Engelmann, 1861.

JASTROW, J. In F. C. Müller-Lyer, Optische Urteilstäuschungen. Arch. Physiol. Suppl. Bd., 1889, 263-270.

LAU, E. Versuche über das stereoskopische Seheri. Psychol. Forsch., 1922, 2, $1-4$.

LIPPS, T. Ästhetische Faktoren der Raumanschauung. Helmholtz-Festschrift, 1891 , p. 217.

MÜLLER-LYER, F. C. Optische Urteilstäuschungen. Arch. Physiol, Suppl $B d ., 1889,263-270$.

OPPEL, J. J. Über geometrisch-optische Täuschungen. Jber, phys Ver. Frankfurt, 1855, 3747.

POGGENDORFF, J. C. mentioned illusion to Zöllner, F. who described it in 1860 , but named for Poggendorff by E. Burmester 1896.

PONZO, M. Rapports de contraste angulaire et l'appréciation de grandeur des astres à l'horizon. Arch. Ital d. Biol, 1912, 58, 327-329.

SPRINGBETT, B. M. Some stereoscopic phenomena and their implications. Brit. J. Psychol, 1961, 52, 105-109.

TITCHENER, E. B. Experimental Psychology: A Manual of Laboratory Practice. New York: Macmillan, 1901.

WUNDT, W. Die geometrisch-optischen Täuschungen. Abhandl der sächs. Ges d. Wiss, math-phys C., 1898, 24, 53-178.

ZÖLLNER, F. Über eine neue Art von Pseudoskopie und ihre Beziehungen zu den von Plateau und Oppel beschrieben Bewegungsphänomenen. Ann. Phys. Chem, 1860, 186, 500-520.

\section{NOTE}

1. The author is indebted to Dr. Gerald H. Fisher for his guidance in this project.

(Accepted for publication March 20, 1968.) 